\title{
A NORMATIVE APPROACH TO WELFARE ATTITUDES
}

\author{
Christian Staerklé, Tïna Likeki \& Régis Scheidegger
}

Staerklé, C., Likki, T., \& Scheidegger, R. (2012). A normative approach to welfare attitudes. In S. Svallfors (Ed.) Contested Welfare States: Welfare Attitudes in Europe and Beyond (pp. 81-118). Stanford: Stanford University Press.

Citizens have many different reasons to support or oppose government responsibility in the domain of social welfare. They may want to restrict social rights for undeserving or deviant beneficiaries, they may want to safeguard their own financial interests, they may want to exclude immigrants and other outgroups from welfare coverage, or they may express solidarity with fellow citizens in precarious life situations. Such reasons are likely to determine the extent to which citizens consider government institutions to be responsible for handling social issues such as inequality, unemployment and public health. The match between citizens' expectations and actual government intervention in social issues then shapes the legitimacy of welfare arrangements, thus providing the social foundation of collective responsibility.

We use the generic term of normative beliefs to subsume individually held, but socially shared values, perceptions and expectations which provide normative support for welfare attitudes, understood as policy preferences in the domain of government responsibility and redistribution of economic resources. Four issues related to normative beliefs are addressed in this chapter. The first issue concerns the structure of the beliefs which are associated with welfare attitudes. We suggest that four basic categories of beliefs account for the normative foundation of welfare intervention, organised as a function of different conceptions of social order. Second, we investigate the social contexts which give rise to these normative beliefs by studying how level of education and perceived vulnerability impacts normative beliefs and welfare attitudes. A third 
question concerns the nature of the relationship between normative beliefs and welfare attitudes. We propose that social psychological processes of differentiation and boundary definition provide the normative foundations of welfare legitimacy. And fourth, we investigate contextual variation of these beliefs by examining how membership in different European countries moderates the role of normative beliefs as organizing principles of welfare attitudes.

In order to tackle these issues, we develop a normative approach to welfare attitudes that sets out to explain the psychological and cultural processes which account for the relationship between social position, normative beliefs and policy attitudes. Two empirical strategies will be used: First, we propose a mediation model of welfare attitudes with individual social position as the independent variable, welfare attitudes as the outcome variable and theoretically defined normative beliefs as mediating variables between social position and policy attitudes. Second, we investigate the relationships between normative beliefs and welfare attitudes as a function of national and institutional contexts, first by comparing the impact of normative beliefs as a function of welfare regimes, and second through multilevel modelling.

\section{Cultural approaches to welfare attitudes}

The question of public legitimacy of social government intervention has attracted much recent scholarly interest (e.g., Aalberg, 2003; Andreß and Heien, 2001; Blekesaune and Quadagno, 2003; Mau, 2003; Mau and Veghte, 2007; van Oorschot, 2006; Staerklé et al., 2007; Svallfors, 2006). Many accounts of perceived government legitimacy rely on the assumption that self-interest is a key driving force of welfare attitudes (e.g., Hall and Soskice, 2001; Rehm, 2007). Yet, this rationalist view of human motivation whereby citizens support only those policies they benefit from has been challenged by researchers who emphasize the importance of normative, moral and cultural factors in explaining political attitudes (e.g., Mau, 2004; Sears and Funk, 1990; van Oorschot, 2006). A cultural approach to welfare attitudes, for example, suggests that 
members of a cultural community elaborate, share and perpetuate meanings of the role of government in their everyday lives (see Clarke, 2004; Chamberlayne et al., 1999; van Oorschot, 2006). The encompassing Nordic welfare states have for example been explained with the historically prevailing Lutheran model of the relationship between a caring central authority and citizens who willfully subject themselves to this authority (Soerensen, 1998). Self-interest itself may be such a cultural norm rather than an inherently individual motivation (Miller, 1999b). In this view, self-interest is perceived by citizens (and maybe also by large parts of the "elite" such as policy makers and researchers) of the Western world not only as the most "normal" explanation of human behavior ("everybody is self-interested"), but also as the most appropriate justification (“it's good to be self-interested").

A cultural analysis of policy attitudes also focuses on widely shared beliefs about beneficiary groups and cultural patterns of perceived deservingness. In such analyses, the impact of normative images of the poor (Geremek, 1994) and perceptions of causes of poverty are studied as policy attitude determinants (e.g., Sachweh et al., 2007; van Oorschot, 2000). One widespread cultural belief about the origins of social hardship is welfare dependency according to which government intervention is actually the problem rather than the solution to the dire consequences of life course misfortunes. In line with neo-conservative ideology (e.g., Murray, 1984), overly generous welfare policies are claimed to lead to attitudes of passivity, immorality, selfishness, consumerism and hedonism. Notwithstanding the fact that research has not been able to empirically uncover such deleterious effects of welfare states, cultural beliefs about welfare dependency remain powerful rhetorical devices to justify welfare retrenchment.

This cultural focus on welfare attitudes reflects contemporary value pluralism (e.g., Young, 2007) which also guides our normative approach. In a far-reaching analysis on the cultural values underlying welfare attitudes, Feldman and Zaller (1992) show that political cultures of countries provide people with ideological values which often conflict with each other. 
In their analysis of policy attitudes in the United States, they describe a central conflict between the cultural values of individualism and humanitarianism, a classical distinction many authors have referred to, for example in terms of a conflict between capitalism vs. democracy (McClosky and Zaller, 1984), the protestant work ethic vs. egalitarianism-humanitarianism (Katz and Hass, 1988), or freedom vs. equality (Rokeach, 1973). The value pluralism of contemporary political cultures gives rise to widespread attitudinal ambivalence which is therefore not the result of lacking political competence: "[...] conflict and ambivalence is interpreted not as confusion, inconsistency, or lack of sophistication but as a problem of reconciling the multiple values, beliefs, and principles simultaneously present in the political culture" (Feldman and Zaller, 1992: 270). A comparative analysis of welfare attitudes should take into account that contemporary political cultures across different national contexts are characterized by a large array of competing cultural values and models of social organization (Hochschild, 1981). Such value configurations represent normative reference markers which feed and orient lay political thinking (Young, 2007) and are presumably present in any democratic society as "ideological dilemmas" (Billig, 1989).

Yet, a cultural approach may be prone to a conceptual pitfall when individuals are seen as unidirectionally "influenced" by cultural beliefs which are supposedly shared to an equal degree by members of a given social group. Instead, it seems more fruitful to consider such cultural beliefs as the product of everyday practice, social experience and membership in social groups, and thus as organizing principles of social relations and social order (Staerklé, 2009).

\section{A normative approach to welfare attitudes}

The normative approach to welfare attitudes we offer in this chapter is based on classic work in European social psychology (Doise, 1986; Moscovici, 1961/1976; Tajfel, 1978; 1981), in particular social representations theory which was initiated in the 1960's by Serge Moscovici (see Augoustinos et al., 2006; Bauer and Gaskell, 2008; Doise et al., 1993; Moscovici, 2000). At the 
most general level, social representations are collective definitions of reality, made up by shared normative beliefs which enable communication, consent and dissent within and between social groups (Elcheroth et al., in press; Staerklé et al., in press). Social representations are not "external" to individuals, in the sense that they would exert an "influence" on them. Rather, individuals' thinking is based on representations without which they could not make sense of social realities and communicate with each other about these realities. Social representations therefore organize social relationships by providing normative reference knowledge-expressed as "values", "beliefs", or "identities"—-which make up the symbolic environment of citizens and their various ingroups.

A social representational account of welfare attitudes conceptualizes lay thinking as based on rules and principles different from formal expert thinking. Welfare attitudes are seen as part of political lay thinking (Staerklé, 2009) which is fed by widely disseminated ideas and shared understandings regarding social order and the just distribution of resources within a society (see Mau, 2004), in particular as a function of the perceived entitlement of potential beneficiary groups. Normative beliefs are thus seen as collectively elaborated and shared knowledge that reflects different models of organizing a society, that is, conceptions of social order.

In its most basic sense, the notion of social order refers to the norms, rules and laws which define our living together as a group, as a community or as a society. Welfare attitudes should therefore be understood in relation to the normative beliefs which underlie social order and make the social bond possible (van Oorschot and Komter, 1998). But because democratic dissent can always challenge an established way to organize the society, any order may be contested and its stability can never be taken for granted. Such competing models of social order prescribe different types of relationships between individual members, their reference groups and the institutions and authorities which govern them. Some forms of social order, for example, emphasize the collective interests of the group to which individual rights and duties are 
subordinated, whereas others value individual rights which have priority over community rights. It is our assumption that citizens refer to such competing models of social order when taking up a stance towards social government intervention.

Hence, we view normative beliefs such as egalitarianism, authoritarianism or welfare dependency as reflecting specific conceptions of social order debated in the public sphere rather than as individual values or even personality dimensions. The differential endorsement of these beliefs reflects the support or the rejection of normative models of social order put forward by political groups, policy makers and other voices heard in the political debate. Normative beliefs therefore function as organizing principles (Bourdieu, 1984; Doise et al., 1993) of welfare attitudes which crystallize competing definitions of social order. The relative individual importance of these representations of social order as foundations of welfare attitudes varies according to one's position in the social hierarchy. In our mediation model, we focus on individual variation of conceptions of social order as a function of education and perceived vulnerability (see Lewin-Epstein et al., 2003).

The normative beliefs underlying welfare attitudes will be organized on the basis of the model of lay conceptions of social order (Staerklé, 2009). Originally developed to analyze the Swiss Welfare State Survey (Staerklé et al., 2007), this model distinguishes four domains of shared normative beliefs called Moral order, Free market, Social diversity and Structural inequality. These domains refer to four prototypical forms of social order which allow integrating various belief items contained in ESS 4 into a single, theory-based framework of normative beliefs. On the individual level, these conceptions are not mutually exclusive, but rather combine in multiple ways.

The model assumes that the basic psychological process underlying normative beliefs is differentiation between social categories (Tajfel, 1978) and boundary definition (Lamont and Molnar, 2002). Through differentiation, the multiple boundaries between positively connoted, 
deserving social categories and negatively connoted, undeserving categories are subjectively defined. Differentiation thereby translates value conflicts at a societal level into a psychological process which sets apart positively evaluated ingroups and negatively evaluated outgroups, organizes perceptions of cleavages within the society, and ultimately determines perceived entitlements of social categories. Such a view is in line with political theory which emphasizes the central role of social antagonisms in democratic politics (Mouffe, 1993). This perspective suggests that policy decisions are basically strategies to regulate relations between groups and individuals representing contrasting values. Such antagonisms are also thought to be at the core of normative beliefs.

The four conceptions of social order-Moral order, Free market, Social diversity and Structural inequality — represent the outcome of the crossing of two fundamental polarities which organize normative beliefs as: (a) normative vs. categorical differentiation which occur in (b) social contexts defined either by identity (symbolic) or positional (material) concerns (see Table 5.1). Normative differentiation (Moral order and Free market) establishes boundaries between norm-conforming and norm-violating individuals, while categorical differentiation (Social diversity and Structural inequality) creates boundaries between groups defined by ascribed group membership (Duckitt, 2001; Kreindler, 2005). In the process of normative differentiation, social cleavages are understood as the result of wilful individual actions, for example in normative beliefs which imply a distinction between lazy and hard-working people such as welfare dependency. The meaning of these actions is defined with respect to perceived conformity with important ingroup values, in this example the work ethic, and the boundaries are represented as permeable (anyone can work hard if they only want to). The process of categorical differentiation, in turn, is reflected in normative beliefs which pit against each other social categories defined through ascribed membership. Boundaries are therefore constructed as impermeable, such as in relations between ethnic and cultural minorities and majorities (as in the 
normative belief of ethnocentrism) or between subordinate and dominant groups (as in beliefs of social dominance). These two forms of differentiation processes can either rely on identity-based, non-quantifiable criteria (Moral order and Social diversity), or on material and quantifiable attributes (Free market and Structural inequality). This second polarity thus opposes boundary definitions related to social identities and symbolic motives on the one hand, and to social position, social hierarchy and instrumental motives on the other.

The four conceptions represent simplified models of social order, and the normative beliefs which reflect these conceptions are deployed and debated in the political arena, for example by interest groups who seek to define and impose specific meanings of social categories (such as the "lazy unemployed"). By specifying an emblematic antagonism for each type of social order, the model seeks to account for the key role played by stereotypical images of beneficiary groups in welfare attitude construction. Four types of perceived entitlements are defined by the model. The perceived legitimacy of welfare benefits is based on similarity and value conformity in the Moral order conception, equity and individual contributions in the Free market conception, ascribed group membership in the Social diversity conception, and social position in the Structural inequality conception. The analysis of the relationships between normative beliefs and welfare attitudes are presumed to provide indirect evidence of how perceived entitlements lead to supporting or opposing intervention in the domain of social welfare.

Normative beliefs are expected to interact with the institutional environment which is at the same time the source and the product of shared definitions of reality: while institutional arrangements grow out of pre-existing belief and value systems, they also give rise to new beliefs and consolidate existing ones. Analyses of the match between collective levels of support for welfare arrangements and national welfare regimes are based on the assumption that national welfare institutions exert a socializing and norm-stabilizing force which influences public opinion (Andreß and Heien, 2001). Our approach shares the important assumption with such normative 
institutionalist approaches that the norms and rules of institutions shape the actions of those acting within them (e.g., Mau, 2004; Rothstein, 1998). But in contrast to Mau’s (2004) institutionalist model which takes national arrangements (weak vs. strong conditionality and comprehensive vs. residual level of welfare provision) as the defining dimensions of normative conceptions of reciprocity, our model of lay conceptions of social order takes a more bottom-up approach based on normative beliefs held by citizens and the psychological processes implied by these beliefs. Yet, our normative approach also assumes a homology between social-institutional and cognitive-psychological regulation.

Accordingly, perceived welfare legitimacy (or illegitimacy) should be based on normative beliefs, evidenced with correlations between welfare attitudes and normative beliefs). These relationships are expected to vary according to the normative environments provided by different national and institutional contexts. We empirically analyze such institutional variation, first with comparisons of the role of normative beliefs in predicting welfare attitudes across types of welfare regimes (Esping-Andersen, 1990). Second, we employ multilevel models to test the impact of two continuous country-level variables, the proportion of social expenditure of a country and its level of unemployment. Social expenditure was chosen because in strong welfare states the question of defining boundaries between beneficiaries and non-beneficiaries of social provisions is likely to be a central political question, and thus relevant for the analysis of public welfare legitimacy. The model of lay conceptions of social order appears suitable to explore this issue since it conceptualizes normative beliefs as strategies of differentiation and boundary definition which support or undermine the legitimacy to government intervention. Level of unemployment, in turn, should affect the extent to which citizens are personally aware of social risk and uncertainty, through their own experience of unemployment and familiarity with unemployed persons around them. In order to provide more detailed rationales as to how the 
country-level features should affect the legitimizing role of normative beliefs, we now move on to examine separately the four conceptions of social order.

\section{Table 5.1 about here}

\section{Four conceptions of social order}

In the conception of Moral order, social order is based on the principle of morality and conformity with consensual and established norms and values (as in Etzioni's, (1994), conservative communitarianism). Social order is explained with citizens' respect for common values such as morality, self-reliance and discipline: the good citizens are those who represent "our" values, whereas those who disrespect them, with deviant and disorderly behavior, are categorized as "bad" citizens. This form of social order is supported and justified with authoritarian modes of thinking, characterized by intolerance of deviance and submissiveness to authorities (see Duckitt, 1989).

Two rationales linking authoritarian beliefs to welfare attitudes seem plausible. Firstly, an authoritarian view of social order may be incompatible with the endorsement of extensive government responsibility in that repression of deviance, rather than redistribution, is seen as the correct answer to social problems. In this view, deviant and non-conforming individuals are not considered worthy of state support, leading to a conditional view of welfare and lower overall levels of welfare support. Some authors have already noted a current tendency in many West European countries to complement or even substitute social welfare schemes with punitive and repressive policies (see Garland, 2001; Young, 1999). In sum, the first hypothesis suggests that a negative relationship between authoritarian beliefs and welfare support would imply a perceived incompatibility between social and repressive government action ("the more 
authoritarian, the less social government intervention”, H1a). We would expect to find such a relationship particularly in West European liberal contexts where high levels of social expenditure have come under political attack from neo-liberal movements and where the shift from social to penal regulation of social problems has been most clearly evidenced (Wacquant, 2009).

An alternative rationale suggests that endorsing both authoritarian beliefs and extensive government responsibility may not necessarily be mutually exclusive. A positive relationship ("the more authoritarian, the more social government intervention", H1b), reflects support for a strong government which is expected both to help people in need and to deal effectively with crime and other forms of social insecurity. We therefore expect the relationship between authoritarianism and government responsibility to be more strongly positive in national contexts with high levels of social insecurity, in the form of low social expenditure and high unemployment, compared to contexts with relatively less social insecurity.

A second aspect of the moral order conception concerns the extent to which people perceive others as trustworthy group members. Social trust has been shown to be central for coordination and cooperation within groups (Deutsch, 1973; Putnam, 1993). We can therefore expect that social distrust should lead to a lower willingness to support resource redistribution within the group or society ("the more distrust, the less social government intervention", H2a). An alternative and more counterintuitive hypothesis in light of the research on the positive effects of trust on welfare legitimacy (e.g., Rothstein, 1998), however, suggests a positive relationship ("the more distrust, the more social government intervention", H2b), interpreted as a response to contexts where people feel they cannot trust others and therefore need the state to compensate for the weakened social ties through extensive government programmes. Hence, we expect the relationship between distrust and government responsibility to be positive in contexts of high social insecurity, that is, where social expenditure is low and unemployment high. 
The Free market conception of social order consists of beliefs about competitive motivations which take productivity and individual performance as the basis of normative boundary definition. On grounds of economically liberal principles, free market thinking assumes that the basic human motivation is self-interest (Walster et al., 1987). Meritocratic criteria differentiate lazy "losers" from productive "winners", and individuals are expected to engage in competitive relations with each other. Equity policies (such as individualized insurance regimes) as well as means-tested schemes are the main policy types in this conception. Alleged welfare dependency is therefore a central normative belief in the free market conception. This free market conception of welfare is evidenced with a negative relationship between welfare dependency and government responsibility ("the lazier the beneficiaries, the less government", H3). We expect this free market conception to be widespread across European countries, but nevertheless anticipate that alleged welfare dependency plays a more prominent role in welfare attitude construction in extensive welfare states where unemployment is low because in such contexts welfare abuse is likely to figure more in media and political discourse. Hence, the relationship between welfare dependency and social government intervention should be more strongly negative in these contexts.

The conception of social diversity relies upon ascribed group membership and is based on an a priori distinction between social groups, in particular between national, ethnic and cultural groups. It thereby provides a conceptual framework for integrating beliefs concerning cultural diversity and multiculturalism in the study of welfare attitudes . This conception is more complex than the conceptions of moral order and free market, because normative beliefs in contemporary societies may depict group differences as either positive, for example in multiculturalism and in movements defending rights of particular groups (see Isin and Wood, 1999), or as negative, for example in racist and ethnocentric thinking. We expect to find mostly negative relationships between ethnocentrism and government responsibility across European 
countries ("the more ethnocentric, the less welfare", H4). Such negative relationships are assumed to denote a motivation to limit welfare coverage of immigrant and other minority groups, a process amply illustrated in the U.S. context where racial prejudice towards Blacks is a major driving force of opposition to welfare (Gilens, 1999). We therefore expect the relationship between ethnocentrism and government responsibility to be more negative in national contexts with high levels of social expenditure where immigration is more common and also more politicized (Castles and Miller, 2009).

In the final conception, normative beliefs are structured by perceived social hierarchies of status and power, that is, by structural inequalities. In this conception, boundaries are drawn between allegedly impermeable subordinate and dominant social categories. These categories are seen as being in a competitive relation of negative interdependence with each other: the demands by subordinate groups directly threaten the well-being of the dominant groups. As in the social diversity conception, normative beliefs promoted by politically active groups and individuals can either portray structural inequalities as legitimate, fair and "normal", or on the contrary as illegitimate and unfair. In order to justify social cleavages, individuals may for example endorse beliefs put forward by groups which claim moral, social and intellectual superiority of those in privileged positions (i.e., "legitimizing myths" in social dominance theory, Sidanius and Pratto, 1999), or they may support egalitarian beliefs which consider class differences as the illegitimate result of social reproduction and inherited privileges (Bourdieu, 1984). Therefore, individuals promoting an egalitarian social order are likely to defend redistributive policies, in particular progressive tax policies and universalist social welfare programs (Rothstein, 1998). Welfare legitimacy following the logic of this conception is evidenced with a positive relationship between egalitarianism and government responsibility ("the more egalitarian, the more welfare, H5), denoting a motivation to expand welfare coverage to subordinate groups. Since the need to address inequalities is strongest in countries with high 
levels of social insecurity, we expect this relationship to be more positive in countries with relatively low levels of social expenditure and high levels of unemployment.

\section{Analytic Model}

An analytic model will guide the treatment of the ESS IV data on 28 European countries. In a first step, we examine the dimensionality and the factorial structure of five normative beliefs defined by the model of lay conceptions of social order (Authoritarianism, Distrust, Welfare dependency, Ethnocentrism and Egalitarianism). In a second step, we examine the impact of social position (assessed with level of education and perceived material vulnerability) on the five conceptions of social order (path a in Figure 5.1). Multilevel regression analyses then investigate the joint impact of social position (path b) and normative beliefs (path c) on government responsibility. Next, we present a mediation model which analyses the indirect effects of social position on welfare attitudes, mediated by normative beliefs for all countries together (paths a + c). In order to examine country-level variation of normative welfare legitimacy, we first look at differences and similarities in normative mechanisms across welfare regimes. Then, in the final step, we test cross-level interactions to explore the extent to which the relationships between normative beliefs and welfare attitudes are moderated by two country-level variables, that is, social expenditure and level of unemployment (path d).

Figure 5.1 about here

\section{Data and measures}

We use the complete ESS IV dataset (third release) which in May 2010 included 28 countries (N $\left.=54^{\prime} 988\right)$. Variables were constructed in order to test the mediation model presented in Figure 
5.1. We first describe the social position variables, then the conceptions of social order, and finally the two dependent variables.

Level of education and perceived material vulnerability were used as variables assessing respondents' position in the social structure. Level of education was chosen because it is a reliable and objective indicator of social position. It is highly correlated with other indicators of social position such as household income $(\mathrm{r}=.38)$, and has the advantage of having few missing values (contrary to household income). We assume that the level of education determines to a large extent the social position of individuals in terms of income, status and prestige (Bourdieu, 1984). A single item with seven levels of education was used: (1) not completed primary education (3.2\% of the sample); (2) primary or first stage of basic schooling (12.4\%); (3) lower secondary or second stage of basic schooling (19.4\%); (4) upper secondary (34.6\%); (5) postsecondary, non-tertiary (7.3\%); (6) first stage of tertiary (21.8\%); and (7) second stage of tertiary $(1.1 \%)$. The item was treated as an ordinal variable.

The second indicator of social position was material vulnerability which represents a subjective interpretation of one's social position in terms of the likelihood of being exposed to different material risks. We call this measure material vulnerability based on the assumption that situations of need, scarcity and destitution give rise to feelings of uncertainty, frailty and doubt. The indicator is an aggregate scale composed of four items of perceived likelihood of life course events with negative material consequences occurring in the next 12 months: (1) becoming unemployed and looking for work; (2) having less time for paid work than desired because of the care given to family members; (3) not having enough money for household necessities; and (4) not receiving health care in case of illness. The average Cronbach's alpha is .76 and ranges from .55 in Denmark to .85 in Cyprus. Material vulnerability has a moderate negative correlation with level of education $(\mathrm{r}=-.13)$ which suggests that people with lower levels of education are more likely to find themselves in situations of material vulnerability. 
Fifteen items assessing the four conceptions of social order were selected (Table 5.2). The Moral order conception was measured with two three-item scales of Authoritarianism and Distrust, the Free market conception was represented by a five-item scale of Welfare dependency, the Social diversity conception was measured with a three-item Ethnocentrism scale, and the Structural inequality conception with a single Egalitarianism item.

A principal components analysis with VARIMAX rotation confirmed the organization of these items into the expected dimensions. In order to formally test the factorial structure of these dimensions, a confirmatory factor analysis on four dimensions was then performed, without the single egalitarianism item. A reasonably good model fit confirmed the four-dimensional structure of the items (CFI $=.96$; $\mathrm{RMSEA}=.05)$.

These findings point towards the heuristic value of the model of lay conceptions of social order which organizes normative beliefs into four general, superordinate categories. The structure of normative beliefs is thus defined by differential representations of social order, and composed of two moral order sub-dimensions (Authoritarianism and Distrust), one free market dimension (Welfare dependency), and one social diversity dimension (Ethnocentrism). The single item on egalitarianism is used as a proxy for the structural inequality conception.

With respect to the overall means of these measures presented in Table 5.2, it can be observed that Distrust, Welfare dependency and Ethnocentrism yielded means around the respective midpoints of the scales, that is, there was no clear overall tendency to either refute or support these beliefs. Authoritarianism, however, was supported by a majority of the respondents (means around 4 on a 5-point scale) as was Egalitarianism (mean of 3.72 on a 5-point scale). Yet, important differences between countries are hidden behind these overall means.

Preliminary analyses revealed that the five conceptions were all positively related to each other, with the exception of a negative relationship between welfare dependency and 
egalitarianism $(\mathrm{r}=-.06)$. The overall correlations ranged from .10 (between egalitarianism and ethnocentrism) to .29 (between ethnocentrism and distrust).

Government responsibility, our dependent variable, was measured with four items asking participants to rate the extent to which governments should be responsible for ensuring the following rights.: (1) Job for everyone; (2) Health care for the sick; (3) Standard of living for the

old and; (4) Standard of living for the unemployed. The global mean of the 4-item summary score shows that there is a strong overall tendency to support government intervention $(M=7.81$ on a 10-point scale). A look at the country-by-country statistics reveals that stronger government intervention is expected in Central, East and South European countries.

Table 5.2 about here

\section{Normative beliefs as a function of education level and vulnerability}

Membership in social categories defined for example by gender, age, education or class represents a proxy for contexts in which common experiences are likely to give rise to shared reference knowledge and similar normative beliefs (Bourdieu, 1984). As an example, the socioeconomic position of citizens affects their perceptions of social reality (Wegener, 1987) which leads low status groups to perceive greater social inequality than high status groups (Aalberg, 2003; Staerklé et al., 2007). More generally, people living in unfavorable living conditions are likely to develop worldviews in line with their living conditions (Castel, 1995).

In the present study, we assumed that similar levels of education give rise to relatively similar life experiences and thus to common normative beliefs. Likewise, the common experience of material vulnerability should lead to specific understandings of social reality. We first carried out a series of multilevel regression analyses predicting each of the five conceptions with social 
positions. In terms of the mediation model presented in Figure 5.1, this step thus investigates the relationship between the independent variables and the mediator variables (path a). ${ }^{1}$

With respect to age and gender, the findings show that older generations were more likely to endorse authoritarianism, welfare dependency, ethnocentrism and egalitarianism, but they were somewhat more trusting than younger generations. A similar pattern emerged for gender where women scored higher than men on the same conceptions as older generations, with the exception of perceived welfare dependency (on which men scored higher) and a much weaker effect on ethnocentrism.

Lower levels of education predicted stronger endorsement of all five conceptions. Respondents with lower levels of education were more authoritarian, more distrustful, believed more strongly in the debilitating effects of welfare, and considered immigrant presence as a threat. That is, they were more likely to draw boundaries between norm-conforming and normviolating categories by endorsing beliefs based on normative differentiation and also more likely to establish stronger boundaries between national and immigrant categories. At the same time, however, they also expressed higher support for egalitarianism, thereby supporting a more inclusive boundary definition in the domain social inequality. Material vulnerability, in turn, also led to distrust, ethnocentrism and egalitarianism, but was unrelated to authoritarianism and negatively related to welfare dependency. Overall, education exerted a stronger pressure on opinions than material vulnerability, this difference being particularly striking for authoritarianism and welfare dependency. Distrust, however, was better predicted by (high) vulnerability than by (low) education level. The strong effects of education level are likely to reflect the fact that

\footnotetext{
${ }^{1}$ Since we were mainly interested in the impact of education and vulnerability within countries, these two variables were group-centered within countries (Enders and Tofighi, 2007). By removing between-country variation, this procedure produces unbiased estimates of the relationships between the individual level variables as well as of slope variances.
} 
education determines both cultural and economic capital (Bourdieu, 1984). People with a higher level of education are higher up in the social hierarchy, they are less punitive and more trusting, less suspicious and less ethnocentric, but also less egalitarian. In short, individuals with high status seem more optimistic and more carefree, and less concerned about social issues such as delinquency, welfare abuse and immigrant presence. The definition of normative boundaries and the perception of social cleavages, in turn, is firmly anchored in low status positions, presumably because perceiving society as being structured as a function of clearly differentiated groups provides a sense of ontological stability and security which is more likely to be jeopardized in low status positions (Young, 1999).

\section{Normative legitimacy of social government intervention}

We now turn to the central question of the nature of the relationship between social positions and normative beliefs on the one hand and welfare attitudes on the other. This analysis provides insights into the normative legitimacy of welfare intervention, as it reveals the extent to which normative beliefs are associated with the support for or opposition to social government intervention. In terms of our analytic model, we look at the effects of the independent and mediator variables on the dependent variable.

In order to control for country-level variance in welfare attitudes, we used multilevel regression analysis to test the effects of social positions and conceptions on welfare attitudes. Similarly to the analyses in the previous section, both the two social position variables and the five conceptions were centered around their country means in order to obtain unbiased and comparable estimates of the relationships between individual level variables (Raudenbush and Bryk, 2002: 139).

In the first step, social position variables of education level and material vulnerability were introduced together with age and gender (path b). Regarding age and gender, the findings 
show that elderly people and women expect more government than younger generations and men. Concerning the two social position variables, higher levels of education were related to less support for government responsibility while material vulnerability predicted stronger endorsement of government intervention. In sum, people in dominant social positions were more likely to reject redistributive government policies while people in subordinate positions endorsed them, a result in line with prior research on welfare attitudes (e.g., Svallfors, 2006).

\section{Table 5.3 about here}

In a second step, the five conceptions were introduced in addition to the variables included in the first step (path c, controlling for path b). The strongest effects were found for egalitarianism, welfare dependency and authoritarianism: Social government intervention was supported with a belief based on the illegitimacy of the categorical differentiation between dominant and subordinate groups. The negative effect of welfare dependency suggests that normative boundary drawing between deserving and undeserving beneficiaries, through the belief in the detrimental effects of government help, is a key driving force of opposition to welfare intervention across European countries. While these two factors are well-known in welfare attitude research (e.g., van Oorschot, 2000), the strongly positive effect of authoritarianism is more intriguing. In line with our second rationale (Hypothesis 1b), this finding indicates that social government intervention is backed up with (rather than challenged by) authoritarian beliefs which call for obedience and punitiveness, and thus for a "strong" government that deals effectively with crime and insecurity. On the level of public attitudes, social government thus goes hand in hand with disciplinary government (see Wacquant, 1999). Similarly, and again contrary to the usual assumption that social trust should support welfare intervention (Rothstein, 1998), distrust in fellow citizens fuels calls for social government intervention, but to a lesser degree than authoritarianism. 
Ethnocentrism, finally, also legitimizes opposition to welfare states (presumably in order to limit social rights for immigrants), but since its effect was weaker than any of the other conceptions, its role as a generalized normative foundation of welfare opposition seems minor.

To summarize, the normative legitimacy of European welfare states seems to be grounded in three general belief systems: First, welfare legitimacy is grounded in a principled position of egalitarianism which considers inequalities between dominant and subordinate groups to be a threat to a fair social order. Second, welfare legitimacy is supported with authoritarian beliefs according to which governments should play a more extensive role in safeguarding a social order threatened by immoral and dangerous people, through repressive policies and an emphasis on conformity and obedience. This interpretation is supported by the finding that welfare intervention is also associated with generalized distrust and the feeling that one cannot rely on fellow citizens for help in difficult life situations. Hence, and at odds with the principle that social trust underlies welfare support, people rely on government intervention to compensate for the lack of social support around them. Third, welfare legitimacy is undermined by stereotypical and stigmatizing images which are put forward in the political debate by advocates of a free market organization of social order who aim to restrict social rights for allegedly undeserving citizens. These findings underscore the importance of normative boundary drawing in welfare legitimacy, since beliefs which imply the differentiation of citizens in terms of their conformity with either moral or economic values determine to a large extent perceived welfare legitimacy. Welfare legitimacy is thus supported by the authoritarian credo that more punishment is needed for rulebreakers, while the belief in the ubiquity of free-riding at the expense of hard-working citizens undermines welfare legitimacy.

\section{Mediation model}


The findings in Table 5.3 also showed that the introduction of the conceptions in the model decreased all main effects of the position variables on welfare attitudes, indicating that the impact of these positions on welfare attitudes was at least partially mediated by normative beliefs (see MacKinnon et al., 2007) . This section specifically addresses this mediating function of normative beliefs with structural equation models (SEM), using the global sample of 28 countries. We began by testing a hybrid model in which the effects of the two social position variables (education and material vulnerability) on welfare attitudes were mediated by the five conceptions, without including the direct effects from the position variables to the attitude. ${ }^{2}$ Figure 5.2 sums up the findings for the model.

Figure 5.2 about here

The model resulted in satisfactory fit indices $(\mathrm{CFI}=.93$; RMSEA $=.05) .{ }^{3}$ In line with our expectations, the analysis reveals that four of the five conceptions (with the exception of ethnocentrism) mediated the effects of both position variables on government responsibility (i.e., the indirect effects were significant). As already shown, lower levels of education were related to a greater motivation to differentiate individuals and groups on both normative and categorical grounds. In the second part of the mediation, from the conceptions to the welfare attitudes, only welfare dependency was negatively linked to welfare attitudes, while all other beliefs led to a greater demand for social government intervention.

These mediation analyses thus demonstrate the existence of indirect, mediating effects between social positions and welfare attitudes through normative beliefs, in particular

\footnotetext{
2 The model is a hybrid model because four conceptions as well as the measure of government responsibility were included as latent variables. All other variables were included as observed variables.

${ }^{3}$ The models include one proposed modification (a covariation between two of the welfare dependency items).
} 
authoritarianism, welfare dependency and egalitarianism. It should be noted, furthermore, that individuals with a low level of education display a paradoxical pattern: they endorse authoritarian and egalitarian beliefs which legitimize welfare intervention, while at the same time accepting beliefs of welfare dependency which undermine welfare legitimacy. The explanation of this seeming inconsistency is likely to be found in the strategies low education groups employ to make sense of their unfavorable social position: while calling for strong government intervention to bring more stability and security to their lives, they also use the work ethic as an identity resource to distance themselves from allegedly value-violating and stigmatized groups such as welfare beneficiaries (Castel, 1995). This leads low education groups to endorse beliefs of perceived abuse and welfare dependency. This pattern was not found among individuals with high levels of material vulnerability who perceived less welfare dependency than those with low vulnerability. In other words, material vulnerability is related to beliefs that support welfare legitimacy, not ones that undermine it.

\section{Welfare regimes and normative welfare legitimacy}

Up to now, we have analyzed welfare legitimacy on the entire sample of 28 countries. There are however strong variations in the revealed mechanisms across countries. Normative beliefs concerning social order and attitudes towards welfare states emerge in specific historical and institutional contexts. National citizens are therefore likely to share a common normative heritage that accounts for greater similarities in the beliefs and attitudes of citizens residing within the same country, compared to citizens from different countries. Furthermore, some countries are more similar to each other than others, forming clusters of countries. As a first step towards understanding the country-level variation in normative welfare legitimacy, we look at differences and similarities in normative mechanisms across welfare regimes, by using an adapted version from Esping-Andersen’s (1990) well-known typology. 
The rationale for this analysis is that welfare regimes, much like the conceptions of social order, reflect different normative models of social order, and that some correspondence can be established between the four conceptions and types of welfare regime. While our analysis remains largely exploratory, we nevertheless expect that conceptions of social order should have greater predictive weight of welfare attitudes in matching regimes, that is, dominant normative beliefs should provide stronger justification of welfare legitimacy. The moral order conception is closest to the continental conservative regime with its principles of subsidiarity and private welfare responsibility. Therefore authoritarianism and distrust (as indicators of moral order) should be important predictors in this regime. The free market conception clearly matches the liberal Anglo-Saxon regime with low de-commodification and market-differentiated provisions which should be supported by welfare dependency. The social diversity conception is not represented in Esping-Andersen's typology, but it allows investigating the relationship between negative perceptions of cultural diversity (ethnocentrism) and welfare provision which has been an important focus of recent welfare research (e.g., Banting and Kymlicka, 2006). The structural inequality conception, finally, is closely related to the social democratic Nordic regime with high de-commodification and strong state intervention, and should therefore be backed up by egalitarianism. Eastern and Southern countries are treated as separate types of regimes, notwithstanding important institutional variations within these categories.

We conducted a regression analysis including the two position variables and the five normative beliefs (as well as controlling for age, gender, and country), separately in five welfare regimes. The countries representing each regime were the same as in chapter 3 (see p. XXX), with the only difference that we excluded Switzerland and the Netherlands from the analysis due to the mixed character of these regimes. The standardized Beta-coefficients for the effect of each normative belief on government responsibility by regime are presented in figure 5.3. 
Figure 5.3 about here

Supporting our hypothesis with respect to moral order, the results show that authoritarian beliefs had the greatest positive effect on welfare support in continentalconservative regimes, along with Southern and Eastern regimes (although their effect remains positive everywhere). Demands for normative conformity and repressive policies, then, seem to go hand in hand with support for social government intervention in all regimes. The effects of distrust are less straightforward, as distrust played no role in structuring welfare attitudes in Anglo-Saxon, Continental or Southern regimes, but had a negative effect on welfare support in Nordic countries, and a positive effect in the Eastern regime. Nevertheless the pattern of variation across regimes was similar to the one observed for authoritarianism. In other words, in the East, perceiving other people as untrustworthy and self-interested leads to higher demand for social state intervention while in the North, distrust is linked to less support for government intervention. The results suggest, then, that the effect of trust is dependent on context, as formulated in our two alternative hypotheses for moral order.

The negative effect of welfare dependency on welfare support was strong across all regimes, indicating that perceived welfare abuse seems to be a universal reason to oppose social government intervention. Similarly, egalitarianism had a universally positive effect on welfare support in all regimes, although its effect was (as expected) strongest in the Nordic and weakest in the Eastern regime. Finally, ethnocentrism was unrelated to welfare support in Eastern, Continental and Anglo-Saxon regimes. Ethnocentrism had a negative effect on support for government intervention only in the Nordic and Southern regimes and even there the effects were small compared to other normative beliefs.

\section{A multilevel approach to country-level variation in normative welfare legitimacy}


A regime-based approach gives a first idea of how normative mechanisms differ across groups of countries. Such an approach does not, however, take into account differences between countries within the same regime. This can be achieved by multilevel modeling which allows testing whether continuous variables measured on the country level account for the differences observed between countries.

We began by analyzing the extent to which the two country-level characteristicspublic social security expenditure (as percentage of GDP) and national unemployment rateaffect welfare attitudes. To test their direct effects on welfare attitudes, we conducted separate analyses for both country level variables by introducing them into the multilevel models, including all individual level variables presented in Table 5.3. Social expenditure had a negative $(\mathrm{p}<$ $.05)$ and unemployment rate a positive effect $(\mathrm{p}<.05)$ on welfare support. In other words, in countries with high levels of public social security expenditure, people were less in favor of social government intervention. This is likely to be a compensation effect inasmuch as the desired government intervention depends on the actual level of government intervention. In countries where government already plays an important social role, citizens are less likely to ask for even more government responsibility. It should be noted, however, that even in countries where the overall mean for government responsibility was among the lowest, it still remained clearly on the side of general support for government responsibility. In countries with higher unemployment, people were more in favor of government responsibility, suggesting that the experience and awareness of the risk of unemployment leads to stronger support for government responsibility.

In the next step, we were interested in the extent to which the effect of normative beliefs in explaining welfare attitudes differs across countries. In order to calculate cross-national variation in the relationships between the five conceptions and government responsibility, we ran separate models each incorporating the random slope of one conception (together with all the individual level main effects presented in Table 5.3). The results of the random slope tests show 
that the relationship between each of the conceptions and welfare attitudes varied significantly across countries, that is, normative beliefs did not have the same effect on welfare attitudes across the 28 countries. The slope variance was greatest for authoritarianism, while the slope variances of the other four conceptions were smaller in magnitude. This finding suggests that welfare legitimacy based on a desire for a strong and repressive government varies greatly across countries. The conception with the second largest slope variance was ethnocentrism, indicating that countries also differ in the extent to which embracing or rejecting social diversity organizes attitudes toward government responsibility.

In the final step, we investigated the extent to which the two country-level variables explain the variations in explanatory power of the five normative beliefs. In order to do so, we introduced cross-level interaction terms into the models described above for testing slope variations. We tested one model for each conception-country level variable combination (i.e., one cross-level interaction at a time), and included in each model the main effect of the country-level variable composing the interaction. Table 5.4 summarizes the moderating effects of welfare expenditure and unemployment variables on the belief-attitude relationships.

\section{Table 5.4 about here}

The results show that, with the exception of welfare dependency, the effects of all normative beliefs on support for government responsibility were moderated by the level of social expenditure. The two strongest effects were found for authoritarianism (Figure 5.4a) and ethnocentrism (Figure 5.4b). As predicted, the positive effect of authoritarianism on support for government responsibility was stronger in countries with lower levels of welfare spending (e.g., Estonia, Latvia, Romania, Russian Federation, Turkey), compared to countries with higher levels of welfare spending (e.g. Belgium, Denmark, Finland, France, Germany, Sweden), even though 
the slopes were positively significant for both contexts. In other words, in the (mostly excommunist) contexts characterized by a weak social state and high levels of social insecurity, authoritarianism was a stronger basis of welfare legitimacy than in (mostly) West European national contexts. Egalitarianism showed the same pattern as authoritarianism with a stronger positive relationship between egalitarianism and government responsibility in countries with low welfare expenditure (thereby qualifying the results of the regime analysis which yielded the strongest effect for the Nordic regime, though without formal comparisons of coefficients). Similarly, distrust was positively related to welfare support in countries with low welfare expenditure and unrelated to welfare support in countries with high welfare expenditure. At odds with our expectations, the impact of welfare dependency did not vary across countries, confirming the results of the regime analysis which also suggested that the normative differentiation between deserving and undeserving individuals represents a fairly uniform basis for rejecting welfare intervention across European countries.

\section{Figures 5.4a-c about here}

Ethnocentrism, in turn, did not predict government responsibility in countries with lower social expenditure, but had, as predicted, a negative effect on support for government responsibility in countries with higher levels of social expenditure. It thus appears that in national contexts where the state takes an important role in redistributing resources between citizens, a negative view of social diversity is linked to less support for government involvement. This is an important finding as it suggests that the importance of prejudice and ethnocentrism as delegitimizing forces of welfare states is contingent upon national contexts. It is interesting to note that although higher (mean) levels of ethnocentrism are generally found in East and Central 
European countries, such exclusionary attitudes actually play a more powerful political role in defining welfare attitudes in (West European) countries with highly developed welfare states.

Unemployment rate moderated the effect of all conceptions on support for government responsibility. Authoritarianism and egalitarianism were both more strongly related to government responsibility in countries with higher levels of unemployment (e.g. Spain, Slovakia, Turkey) than in countries with less unemployment (e.g. Denmark, the Netherlands, Norway, Switzerland). Welfare dependency had a stronger negative effect on government responsibility in countries with lower levels of unemployment, suggesting that the prevalence of unemployment attenuates the negative influence of perceived welfare dependency on welfare support. The delegitimizing role of welfare dependency is thus particularly common in relatively well-off contexts. Concerning distrust (Figure 5.4c), perceiving people as self-interested and untrustworthy was related to greater support for government responsibility in countries with high levels of unemployment, while no such link existed in countries with lower levels on unemployment. Finally, ethnocentrism was negatively related to welfare support in countries with low unemployment and unrelated to welfare attitudes in countries with higher unemployment. Again, attitudes toward foreigners play a more important role in determining welfare attitudes in relatively more privileged contexts characterized by low unemployment, compared to the less privileged contexts of high unemployment.

\section{Conclusions}

In this chapter, we proposed a normative approach to welfare attitudes, based on the general idea that welfare attitudes are shaped by widespread normative beliefs which are anchored in citizens' everyday experiences. We showed how five normative conceptions of social orderauthoritarianism, distrust, welfare dependency, ethnocentrism and egalitarianism—were called upon to support or on the contrary undermine the legitimacy of government responsibility in the 
domain of social welfare and the protection of social rights. These shared beliefs are assumed to reflect the outcome of processes of differentiation and boundary definitions between social categories which are expressed in specific types of perceived cleavages in society: between good and bad people, between winners and losers, between immigrants and nationals, and between dominant and subordinate groups.

In a first step, factor analyses confirmed the expected four-fold structure of conceptions of social order: Moral order (measured by authoritarianism and distrust), Free market (measured by welfare dependency), Social diversity (measured by ethnocentrism), and Structural inequality (measured by egalitarianism). The structure proposed by the model of lay conceptions of social order is thus relevant and applicable to comparative international data.

Second, we investigated how level of education and perceived material vulnerability gave rise to the endorsement of normative models of social order. Individuals with lower levels of education systematically expressed greater endorsement of beliefs based on normative boundary drawing, and were thus more prone to perceive social cleavages. Respondents with lower levels of education were more authoritarian, more suspicious of fellow citizens, endorsed more strongly beliefs about the undeservingness of beneficiaries, and held more negative attitudes towards immigrants. At the same time, they were also more egalitarian. Material vulnerability, in turn, was less uniformly related to normative beliefs. A sense of risk and vulnerability gave rise to higher levels of social distrust, ethnocentrism and egalitarianism, but was unrelated to authoritarianism. In contrast to the low education group, materially vulnerable people perceived less welfare dependency than materially secure people. Individuals with material difficulties therefore seem more likely to be aware of the difficulties and life course risks faced by fellow citizens, they may live themselves on welfare benefits, or they may expect that one day they need to resort to welfare benefits. This awareness leads them to reject a label of welfare abusers for themselves or anyone else dependent on benefits. 
Our third question concerned the nature of the relationship between social position, normative beliefs and welfare attitudes. The overall pattern that arose was clear. In line with prior research, members of low status groups, i.e., people with low levels of education and a strong sense of material vulnerability, females and older generations, were more supportive of social government responsibility. With respect to the normative beliefs, authoritarianism, distrust and egalitarianism led to greater support for government responsibility, while perceived welfare dependency and ethnocentrism were associated with less government involvement. The central normative foundations of welfare legitimacy were authoritarianism, welfare dependency and egalitarianism. These findings suggest that perceptions of a dangerous and immoral society where deviance and crime are perceived as a major social problem fuels support for social government intervention, while stigmatizing images of undeserving citizens undermine welfare legitimacy in virtually all European countries. Egalitarianism, in turn, justifies welfare intervention with the principle that excessive inequalities between dominant and subordinate groups are morally unacceptable. Mediation analyses confirmed that the impact of low social positions on the support for welfare intervention was to a considerable extent due to the endorsement of these normative beliefs.

Interestingly, the normative differentiation between good and bad people (authoritarianism and distrust in the Moral order conception) and between deserving winners and undeserving losers (welfare dependency in the Free market conception) produced opposite effects for welfare legitimacy: social government intervention was seen as an appropriate solution for a society marred by lacking value conformity, suggesting that in many instances, people call for both social and repressive government functions in order to deal with life course difficulties. When endorsing the belief that free riders take advantage of the work of productive citizens, however, less rather than more government is the solution. Normative differentiation plays thus a key role, both in supporting and undermining welfare legitimacy. 
On a more general level, our findings suggest that collective definitions of the boundaries of moral communities are a key factor in analyzing welfare legitimacy. Any implementation of justice principles raises the issue of the definition of the boundaries of moral communities, that is, the groups whose members are potential beneficiaries of resource allocation (Miller, 1999a; Opotow, 1990). Because they reflect strategies of boundary definition, perceived entitlements and stereotypical images of beneficiary groups become the normative basis of welfare legitimacy. Based on the model of lay conceptions of social order, we argue that the relationships between normative beliefs and support for government responsibility may illustrate different logics of defining the moral boundaries of welfare recipients. The link between distrust and government responsibility, for example, may indicate that perceived erosion of moral communities fuels calls for institutional regulation and protection, an interpretation supported by the strong association between distrust and material vulnerability. Egalitarianism, in turn, gives rise to an inclusive perception based on extending welfare coverage to those in disadvantaged living conditions. The negative relationship between welfare dependency and government responsibility points to a desire to exclude those who are seen as abusing the welfare system and profiting from others' work. Ethnocentrism was related, although rather weakly, to lower support for general government involvement in ensuring social rights. This can be seen as a strategy of exclusion where immigrants are differentiated from the national ingroup and left outside the network of national solidarity.

Such an interpretation of the results in terms of moral inclusion and exclusion is, however, limited by our operationalisation of the conceptions of social order. While the items provided by the ESS data set certainly tap into normative beliefs and allow testing our model, they do not explicitly ask about the inclusion or exclusion of specific groups in the sphere of welfare. Our interpretation in terms of moral boundaries is therefore based on the social psychological mechanism assumed to orient the way people reason about welfare. Further 
research is needed that more explicitly measures the notion of moral communities and allows developing and specifying this aspect of differentiation and boundary definition.

The fourth and final aim of the chapter was to map and explain the contextual, country-level variation of these normative beliefs as organizing principles of welfare attitudes. In a regime comparison approach, welfare dependency and egalitarianism emerged as consistent predictors of government intervention across welfare regime types. Authoritarianism played the greatest role in structuring attitudes in Eastern, Southern and continental-conservative regimes, while the exclusion of immigrants was mainly of importance in the Nordic regime (see Staerklé et al., 2010). Finally, distrust had opposite effects in the Eastern compared to the Nordic regime.

Multilevel analyses showed that all the relationships between the five conceptions and welfare attitudes varied significantly across countries. In other words, normative beliefs did not have the same weight as predictors of policy attitudes across different national contexts. In countries with relatively low levels of welfare spending as well as in countries with higher levels of unemployment, the positive effects of authoritarianism, distrust and egalitarianism on welfare support were stronger than in countries with higher welfare spending and less unemployment. This finding suggests that in these predominantly ex-communist, East, Central and South European countries, welfare legitimacy is more strongly grounded, first, in a general conception of a strong and authoritarian state which is expected to regulate relations between citizens, and, second, in a principled belief concerning the unfairness of excessive social inequalities. The positive effect of distrust on government responsibility is striking since research on welfare legitimacy tends to assume the contrary relationship and to consider social trust an important foundation of welfare systems (Putnam, 1993; Rothstein, 1998). In contrast, we view individual distrust as a reflection of precarious life situations, characterized by a pessimistic, suspicious and victimizing outlook on life (Castel, 1995). From this perspective, institutionalized welfare 
provisions and social government responsibility may represent a stable and reliable source of support which thereby becomes a way to cope with existential insecurity and vulnerability.

The patterns were less clear for ethnocentrism and welfare dependency, but significant cross-level interactions allow us to conclude that the negative effects of ethnocentrism on welfare support were stronger in countries with higher levels of welfare spending and lower levels of unemployment. In other words, negative attitudes towards immigrants are a key factor in the delegitimizing of welfare states mainly in West European countries. The negative effect of welfare dependency on welfare support, too, was stronger in contexts characterized by lower levels of unemployment. Overall, however, the role of welfare dependency in delegitimizing welfare intervention seems to be more uniform across European countries than the role of the other normative beliefs.

Social expenditure and level of unemployment thus turned out to be important moderators of the social processes underlying welfare legitimacy. In general, these findings then point towards the importance of social conditions in countries in understanding the normative foundations of the social legitimacy of welfare state arrangements.

An important limit of our contextual analysis regards the choice of country-level variables. We chose to focus on social expenditure because we wanted to show how boundary definition strategies were affected by the level of welfare provision in a country (which they clearly did, as our results have shown). Unemployment, in turn, was chosen since it should affect personal awareness of social risk and uncertainty, and thus also moderate strategies of normative boundary definition. Future research could also incorporate country-level measures of the dominant normative context or ideological climate, measured for example by aggregating individual-level attitude data (Sarrasin et al., 2011, in preparation). People are likely to be aware of the dominant norms prevalent in their societies and disseminated through media and public 
discourse. Such country-level norms may prove to be powerful context level influences on people's positioning towards welfare attitudes.

It is a matter of debate whether the country-level variables used in this study (and in other chapters) truly capture something unique about the context and allow identifying characteristics of the national context that in themselves explain cross-national differences in belief-attitude relationships. A different interpretation of our cross-level interactions is that rather than levels of social expenditure and unemployment explaining the differences, such variation would be related to more general country profiles or regimes. For example, we can question whether the more strongly positive effect of authoritarianism on welfare support in countries with lower levels of welfare expenditure is truly related to social spending or has rather something to do with the fact that most countries with low social spending in our sample are former Communist or Southern countries with a history of authoritarian regimes. Our chapter gives no final answer to whether the multilevel approach is fundamentally superior to the regime approach. The two approaches might be best conceived of as complementary rather than competing, in particular since the multilevel approach allows specifying some relations that would remain unnoticed on a regime level.

In sum, the approach advocated in this chapter highlights the importance of motivations other than self-interest in explaining citizen attitudes towards government and social rights. Sharing beliefs which give meaning to everyday experiences, differentiating oneself from others, drawing boundaries between one's group and other groups, as well as participating in the construction of social order through the endorsement of normative beliefs are such motivations explaining citizen attitudes. Our basic goal was thereby to propose an account of social psychological processes at work in the construction of welfare attitudes. Our results demonstrated that such processes are not universal, but rather moderated by the institutional and normative contexts in which they are enacted. The normative beliefs held by individuals 
embedded in social groups thus become key elements for understanding the psychology of welfare attitudes. 


\section{References}

Aalberg, T. 2003. Achieving justice. Comparative public opinions on income distribution, Leiden, Brill.

Andreß, H.-J. \& Heien, T. 2001. Four worlds of welfare attitudes? A comparison of Germany, Norway, and the United States. European Sociological Review, 17, 337-356.

Augoustinos, M., Walker, I. \& Donaghue, N. 2006. Social Cognition: An Integrated Introduction, London, Sage.

Banting, K. \& Kymlicka, W. (eds.) 2006. Multiculturalism and the welfare state. Recognition and redistribution in contemporary democracies, Oxford: Oxford University Press.

Bauer, M. W. \& Gaskell, G. 2008. Social representations theory: A progressive research programme for social psychology. Journal for the Theory of Social Behaviour, 39, 335-353.

Billig, M. 1989. Ideological Dilemmas: A social psychology of everyday dilemmas, London, Sage.

Blekesaune, M. \& Quadagno, J. 2003. Public attitudes toward welfare state policies: A comparative analysis of 24 nations. European Sociological Review, 19, 415-427.

Bourdieu, P. 1984. Distinction: A social critique of the judgement of taste, Cambridge, MA, Harvard University Press.

Castel, R. 1995. Les métamorphoses de la question sociale: Une chronique du salariat, Paris, Fayard.

Castles, S. \& Miller, M. J. 2009. The age of migration. International population movements in the modern world, Guilford, Guilford Press.

Chamberlayne, P., Cooper, A., Freeman, R. \& Rustin, M. 1999. Welfare and culture in Europe. Towards a new paradigm in social policy, London, Jessica Kingsley.

Clarke, J. 2004. Changing welfare, changing states: New directions in social policy, London, Sage.

Deutsch, M. 1973. The Resolution of Conflict, New Haven, CT, Yale University Press.

Doise, W. 1986. Levels of explanation in social psychology, Cambridge, Cambridge University Press.

Doise, W., Clémence, A. \& Lorenzi-Cioldi, F. 1993. The quantitative analysis of social representations, Hemel Hempstead, Harvester Wheatsheaf. 
Duckitt, J. 1989. Authoritarianism and group identification: A new view of an old construct. Political Psychology, 10, 63-84.

Duckitt, J. 2001. A dual process cognitive-motivational theory of ideology and prejudice. In: Zanna, M. P. (ed.) Advances in Experimental Social Psychology. San Diego, CA: Academic Press, 41-113.

Elcheroth, G., Doise, W. \& Reicher, S. in press. On the knowledge of politics and the politics of knowledge: How a social representations approach helps us rethink the subject of political psychology. Political Psychology.

Enders, C. K. \& Tofighi, D. 2007. Centering predictor variables in cross-sectional multilevel models: A new look at an old issue. Psychological Methods, 12.

Esping-Andersen, G. 1990. The Three Worlds of Welfare Capitalism, Cambridge, Polity Press.

Etzioni, A. 1994. The spirit of community, New York, Simon and Schuster.

Feldman, S. \& Zaller, J. 1992. The political culture of ambivalence: Ideological responses to the welfare state. American Journal of Political Science, 36, 268-307.

Garland, D. 2001. The culture of control: Crime and order in contemporary society, Oxford, Oxford University Press.

Geremek, B. 1994. Poverty: A history, Oxford, Blackwell.

Gilens, M. 1999. Why Americans hate Welfare. Race, media and the politics of antipoverty policy, Chicago, University of Chicago Press.

Hall, P. A. \& Soskice, D. (eds.) 2001. Varieties of capitalism. The institutional foundations of comparative advantage, Oxford: Oxford University Press.

Hochschild, J. L. 1981. What's fair? American beliefs about distributive justice., Cambridge, MA, Harvard University Press.

Isin, E. F. \& Wood, P. K. 1999. Citizenship and identity, London, Sage. 
Katz, I. \& Hass, R. G. 1988. Racial ambivalence and American value conflict: Correlational and priming studies of dual cognitive structures. Journal of Personality and Social Psychology, 55, 893-905.

Kreindler, S. A. 2005. A dual group processes model of individual differences in prejudice. Personality and Social Psychology Review, 9, 90-107.

Lamont, M. \& Molnar, V. 2002. The study of boundaries in the social sciences. Annual Review of Sociology, 28, 167-195.

Lewin-Epstein, N., Kaplan, A. \& Levanon, A. 2003. Distributive justice and attitudes toward the welfare state. Social Justice Research, 16, 1-27.

Mackinnon, D. P., Fairchild, A. J. \& Fritz, M. S. 2007. Mediation analysis. Annual Review of Psychology, 58, 593-614.

Mau, S. 2003. The moral economy of welfare states. Britain and Germany compared, London, Routledge.

Mau, S. 2004. Welfare regimes and the norms of social exchange. Current Sociology, 52, 53-74.

Mau, S. \& Veghte, B. (eds.) 2007. Social justice, legitimacy and the welfare state, Hampshire: Ashgate.

Mcclosky, H. \& Zaller, J. 1984. The American ethos. Public attitudes toward capitalism and democracy, Cambridge, Harvard University Press.

Miller, D. 1999a. Principles of social justice, Cambridge, MA, Harvard University Press.

Miller, D. T. 1999b. The norm of self-interest. American Psychologist, 54, 1053-1060.

Moscovici, S. 1961/1976. La psychanalyse, son image et son public, Paris, Presses Universitaires de France.

Moscovici, S. 2000. Social representations: Explorations in social psychology, Cambridge, Polity Press.

Mouffe, C. 1993. The Return of the Political, London, Verso.

Murray, C. 1984. Losing ground, New York, Basic Books.

Opotow, S. 1990. Moral exclusion and injustice: An introduction. Journal of Social Issues, 49, 1-20. 
Putnam, R. D. 1993. Making democracy work: Civic traditions in modern Italy, Princeton, NJ, Princeton University Press.

Raudenbush, S. W. \& Bryk, A. S. 2002. Hierarchical linear models: Applications and data analysis methods, Thousand Oaks, CA, Sage.

Rehm, P. 2007. Who supports the welfare state ? Determinants of preferences concerning redistribution. In: Mau, S. \& Veghte, B. (eds.) Social justice, legitimacy and the welfare state. Hampshire: Ashgate, 47-72.

Rokeach, M. 1973. The nature of human values, NY, The Free Press.

Rothstein, B. 1998. Just institutions matter: The moral and political logic of the universal welfare state, Cambridge, Cambridge University Press.

Sachweh, P., Ullrich, C. G. \& Christoph, B. 2007. The moral economy of poverty: On the conditionality of public support for social assistance schemes. In: Mau, S. \& Veghte, B. (eds.) Social justice, legitimacy and the welfare state Hampshire: Ashgate, 123-142.

Sarrasin, O., Green, E. G. T., Fasel, N., Christ, O., Staerklé, C. \& Clémence, A. 2011, in preparation. Opposition to anti-racism laws across Swiss municipalities: A multilevel analysis.

Sears, D. O. \& Funk, C. L. 1990. The limited effect of economic self-interest on political attitudes of the mass public. Journal of Behavioural Economics, 19, 247-271.

Sidanius, J. \& Pratto, F. 1999. Social dominance: An intergroup theory of social bierarchy and oppression, New York, Cambridge University Press.

Soerensen, A. 1998. On kings, pietism and rent-seeking in Scandinavian welfare states. Acta Sociologica, 41, 363-375. 
Staerklé, C. 2009. Policy Attitudes, Ideological Values and Social Representations. Social and Personality Psychology Compass, 3, 1096-1112.

Staerklé, C., Clémence, A. \& Spini, D. in press. Social representations: A normative and dynamic intergroup approach. Political Psychology.

Staerklé, C., Delay, C., Gianettoni, L. \& Roux, P. 2007. Qui a droit à quoi ? Représentations et légitimation de l'ordre social [Who is entitled to what? Representations and legitimation of social order], Grenoble, Presses Universitaires de Grenoble.

Staerklé, C., Sidanius, J., Green, E. G. T. \& Molina, L. E. 2010. Ethnic minority-majority asymmetry in national attitudes around the world: A multilevel analysis. Political Psychology, 31, 491-519.

Svallfors, S. 2006. The moral economy of class, Stanford, Stanford University Press.

Tajfel, H. 1978. Differentiation between social groups, Cambridge, Cambridge University Press.

Tajfel, H. 1981. Human groups and social categories: Studies in social psychology, Cambridge, Cambridge University Press.

Van Oorschot, W. 2000. Who should get what, and why? On deservingness criteria and the conditionality of solidarity among the public. Policy \& Politics, 28, 33-48.

Van Oorschot, W. 2006. Culture and social policy: A developing field of study. International Journal of Social Welfare, 16, 129-139.

Van Oorschot, W. \& Komter, A. 1998. What is it that ties...? Theoretical perspectives on social bond. Sociale Wetenschappen, 3, 5-24.

Wacquant, L. 1999. Les prisons de la misère, Paris, Éditions Raisons d'Agir.

Wacquant, L. 2009. Punishing the Poor: The Neoliberal Government of Social Insecurity, Durham, Duke University Press.

Walster, E., Walster, G. W. \& Berscheid, E. 1987. Equity: Theory and research, Boston, Allyn and Bacon. 
Wegener, B. 1987. The illusion of distributive justice. European Sociological Review, 3, 1-13.

Young, J. 1999. The Exclusive Society: Social Exclusion, Crime and Difference in Late Modernity, London, Sage.

Young, J. 2007. The vertigo of late modernity, London, Sage. 
Table 5.1 Model of lay conceptions of social order

\begin{tabular}{|c|c|c|}
\hline & Social identity & Social position \\
\hline & \multicolumn{2}{|l|}{ Normative differentiation } \\
\hline Conception & MORAL ORDER & FREE MARKET \\
\hline Principle of categorization & Morality & Productivity \\
\hline Core antagonisms & "Good” \& "Bad" & "Winners" \& "Losers" \\
\hline Principle of social regulation & Conformity, Similarity & Equity, Self-Interest \\
\hline \multirow{2}{*}{ Welfare policies } & Private support, & Private responsibility, \\
\hline & Charity & Insurance \\
\hline \multirow[t]{2}{*}{ Normative belief } & Authoritarianism, Distrust & \multirow[t]{2}{*}{ Welfare dependency } \\
\hline & Categorical differentiation & \\
\hline \multirow{2}{*}{ Conception } & \multirow{2}{*}{ SOCIAL DIVERSITY } & STRUCTURAL \\
\hline & & INEQUALITY \\
\hline Principle of categorization & Social heterogeneity & Social class, status \\
\hline Core antagonisms & Majority \& Minority & Dominants \& Subordinates \\
\hline Principle of social regulation & Intergroup differentiation & Inequality management \\
\hline \multirow{2}{*}{ Welfare policies } & Majority favoritism vs. & Elite favoritism vs. \\
\hline & Group rights & Redistribution \\
\hline \multirow{2}{*}{ Normative beliefs } & Ethnocentrism vs. & Social dominance vs. \\
\hline & Multiculturalism & Egalitarianism \\
\hline
\end{tabular}


Table 5.2 Five measures of conceptions of social order, with descriptive statistics for overall sample

\begin{tabular}{|c|c|c|c|c|c|}
\hline Conception & Indicator (scale) & Item & $M$ & $S D$ & $N$ \\
\hline \multirow[t]{6}{*}{ Moral order } & $\begin{array}{l}\text { Authoritarianism } \\
(1-5)\end{array}$ & $\begin{array}{l}\text { Terrorist suspect in prison until police } \\
\text { satisfied }\end{array}$ & 4.08 & .99 & 53300 \\
\hline & & Schools teach children obey authority & 4.06 & .94 & 54603 \\
\hline & & $\begin{array}{l}\text { People who break the law much harsher } \\
\text { sentences }\end{array}$ & 3.97 & .97 & 53736 \\
\hline & Distrust & You can’t be too careful & 5.32 & 2.58 & 54786 \\
\hline & $(0-10)$ & Most people try to take advantage of you & 4.73 & 2.47 & 54360 \\
\hline & & People mostly look out for themselves & 5.47 & 2.45 & 54626 \\
\hline \multirow[t]{5}{*}{ Free market } & Welfare & Social benefits make people lazy & 2.97 & 1.14 & 53374 \\
\hline & $\begin{array}{l}\text { dependency } \\
(1-5)\end{array}$ & $\begin{array}{l}\text { Social benefits make people less willing } \\
\text { care for one another }\end{array}$ & 2.90 & 1.09 & 52778 \\
\hline & & $\begin{array}{l}\text { Social benefits make people less willing } \\
\text { look after themselves/family }\end{array}$ & 2.78 & 1.08 & 52773 \\
\hline & & $\begin{array}{l}\text { Most unemployed people do not really try } \\
\text { to find a job }\end{array}$ & 3.05 & 1.11 & 53770 \\
\hline & & $\begin{array}{l}\text { Employees often pretend they are sick to } \\
\text { stay at home }\end{array}$ & 3.02 & 1.09 & 51484 \\
\hline \multirow[t]{3}{*}{ Social diversity } & Ethnocentrism & Immigration bad for country's economy & 5.21 & 2.49 & 51762 \\
\hline & $(0-10)$ & $\begin{array}{l}\text { Country's cultural life undermined by } \\
\text { immigrants }\end{array}$ & 4.65 & 2.61 & 51801 \\
\hline & & $\begin{array}{l}\text { Immigrants make country worse place to } \\
\text { live }\end{array}$ & 5.25 & 2.36 & 51532 \\
\hline $\begin{array}{l}\text { Structural } \\
\text { inequality }\end{array}$ & $\begin{array}{l}\text { Egalitarianism } \\
(1-5)\end{array}$ & $\begin{array}{l}\text { For a society to be fair, differences in } \\
\text { standard of living should be small }\end{array}$ & 3.72 & .97 & 53799 \\
\hline
\end{tabular}


Table 5.3 Multilevel analysis: Level-1 Main Effects of Social Positions and Conceptions on Welfare Attitudes

\begin{tabular}{|c|c|c|c|c|}
\hline & \multicolumn{4}{|c|}{ Government responsibility } \\
\hline & \multirow{2}{*}{\multicolumn{2}{|c|}{$\begin{array}{c}\text { M2a } \\
\text { Social Positions }\end{array}$}} & \multirow{2}{*}{\multicolumn{2}{|c|}{$\begin{array}{c}\mathrm{M} 2 \mathrm{~b} \\
\text { Conceptions }\end{array}$}} \\
\hline & & & & \\
\hline & $B$ & SE & $B$ & SE \\
\hline \multicolumn{5}{|l|}{ Level 1} \\
\hline Intercept & $76.96^{* * *}$ & $(1.11)$ & $77.17 * * *$ & $(1.11)$ \\
\hline \multicolumn{5}{|l|}{ Social Position } \\
\hline Age & $.63 * * *$ & $(.07)$ & $.28 * * *$ & $(.07)$ \\
\hline Female & $1.36 * * *$ & $(.14)$ & $.95^{* * *}$ & (.13) \\
\hline Education & $-1.20 * * *$ & $(.08)$ & $-.84 * * *$ & $(.08)$ \\
\hline Material Vulnerability & $1.34 * * *$ & $(.08)$ & $1.01 * * *$ & $(.08)$ \\
\hline \multicolumn{5}{|l|}{ Conceptions } \\
\hline Authoritarianism & & & $2.42 * * *$ & $(.08)$ \\
\hline Distrust & & & $.53 * * *$ & $(.08)$ \\
\hline Welfare Dependency & & & $-3.24 * * *$ & $(.07)$ \\
\hline Ethnocentrism & & & $-.30 * * *$ & $(.08)$ \\
\hline Egalitarianism & & & $3.27 * * *$ & $(.07)$ \\
\hline \multicolumn{5}{|l|}{ Level 2} \\
\hline$\Delta-2 \log$ likelihood (df) & \multicolumn{2}{|c|}{$824.2(4) * * *$} & \multicolumn{2}{|c|}{$5092.5(5)^{* * *}$} \\
\hline
\end{tabular}

Note. Dependent variable scale ranges from 0 to 100. All predictor variables (except gender) are standardized. -2 Log Likelihood difference for the M2a model is calculated in comparison to the intercept only model. -2 Log Likelihood difference for the M2b model is calculated in comparison to the M2a model.

$*=p<.05 . * *=p<.01 . * * *=p<.001$. 
Table 5.4 Multilevel analysis: Cross-Level Interactions between Conceptions and Level-2

\section{Indicators on Welfare Attitudes}

\begin{tabular}{|c|c|c|c|}
\hline & & $\begin{array}{l}\text { Gove } \\
\text { respo }\end{array}$ & $\begin{array}{l}\text { ent } \\
\text { ility }\end{array}$ \\
\hline & & $B$ & SE \\
\hline Level 2 Indicator & Level 1 Conception & & \\
\hline Social Expenditure * & Authoritarianism & $-.94 * *$ & (.33) \\
\hline & Distrust & $-.66 * *$ & $(.22)$ \\
\hline & Welfare dependency & -.11 & $(.21)$ \\
\hline & Ethnocentrism & $-.70 * *$ & $(.23)$ \\
\hline & Egalitarianism & $-.53^{*}$ & $(.21)$ \\
\hline Unemployment Rate* & Authoritarianism & $.75^{*}$ & $(.34)$ \\
\hline & Distrust & $.60^{*}$ & (.23) \\
\hline & Welfare dependency & $.40^{*}$ & (.19) \\
\hline & Ethnocentrism & $.60^{*}$ & $(.24)$ \\
\hline & Egalitarianism & $.46^{*}$ & $(.22)$ \\
\hline
\end{tabular}

Note. The cross-level interaction models are compared to their respective random-slope models. Underlined interaction effects are depicted in figures $5.4 \mathrm{a}-\mathrm{c}$.

$*=p<.05 . * *=p<.01 . * * *=p<.001$. 
Figure 5.1 Mediation model of welfare attitudes

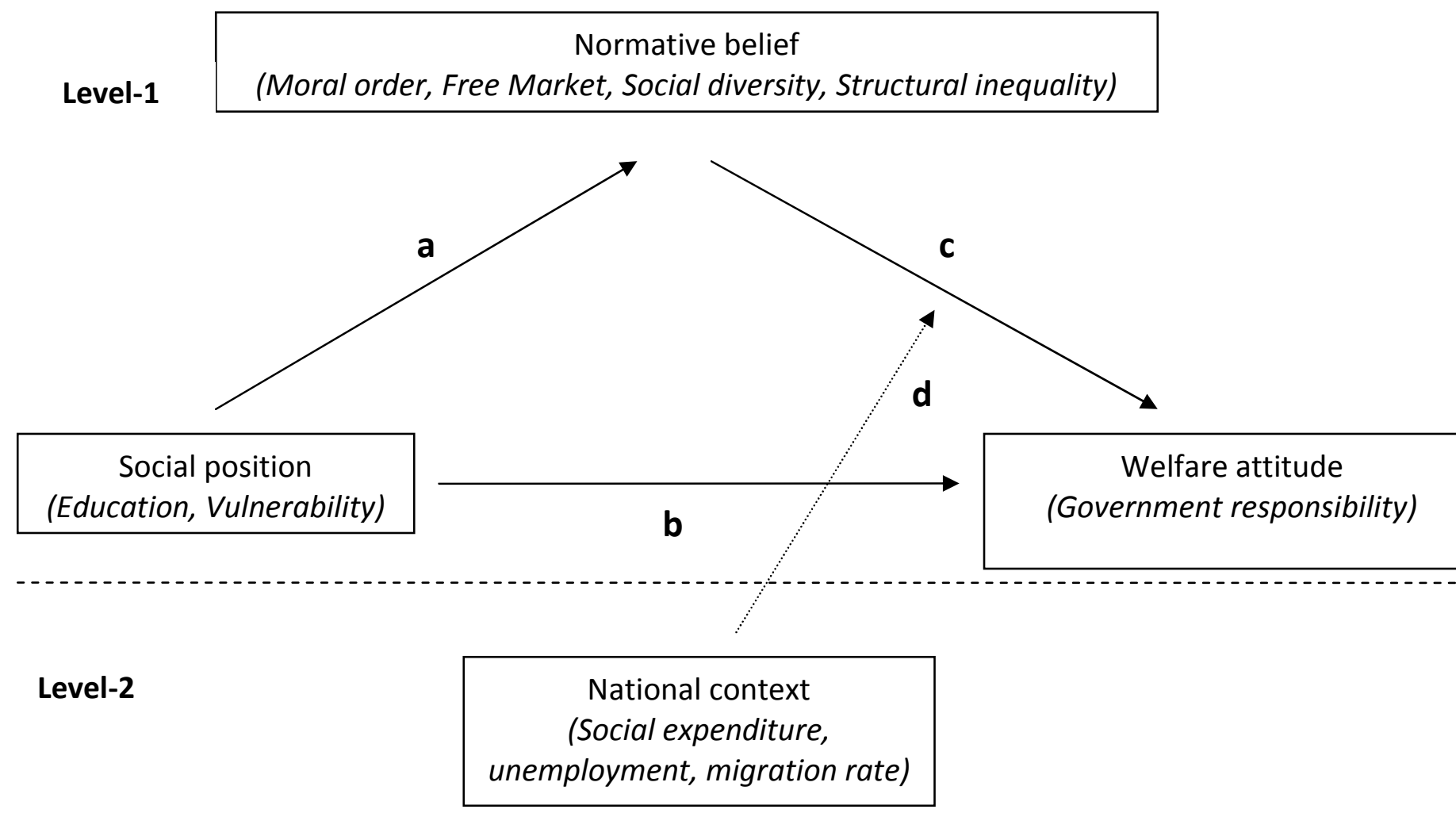


Figure 5.2 Normative beliefs mediate the link between social position and welfare attitudes

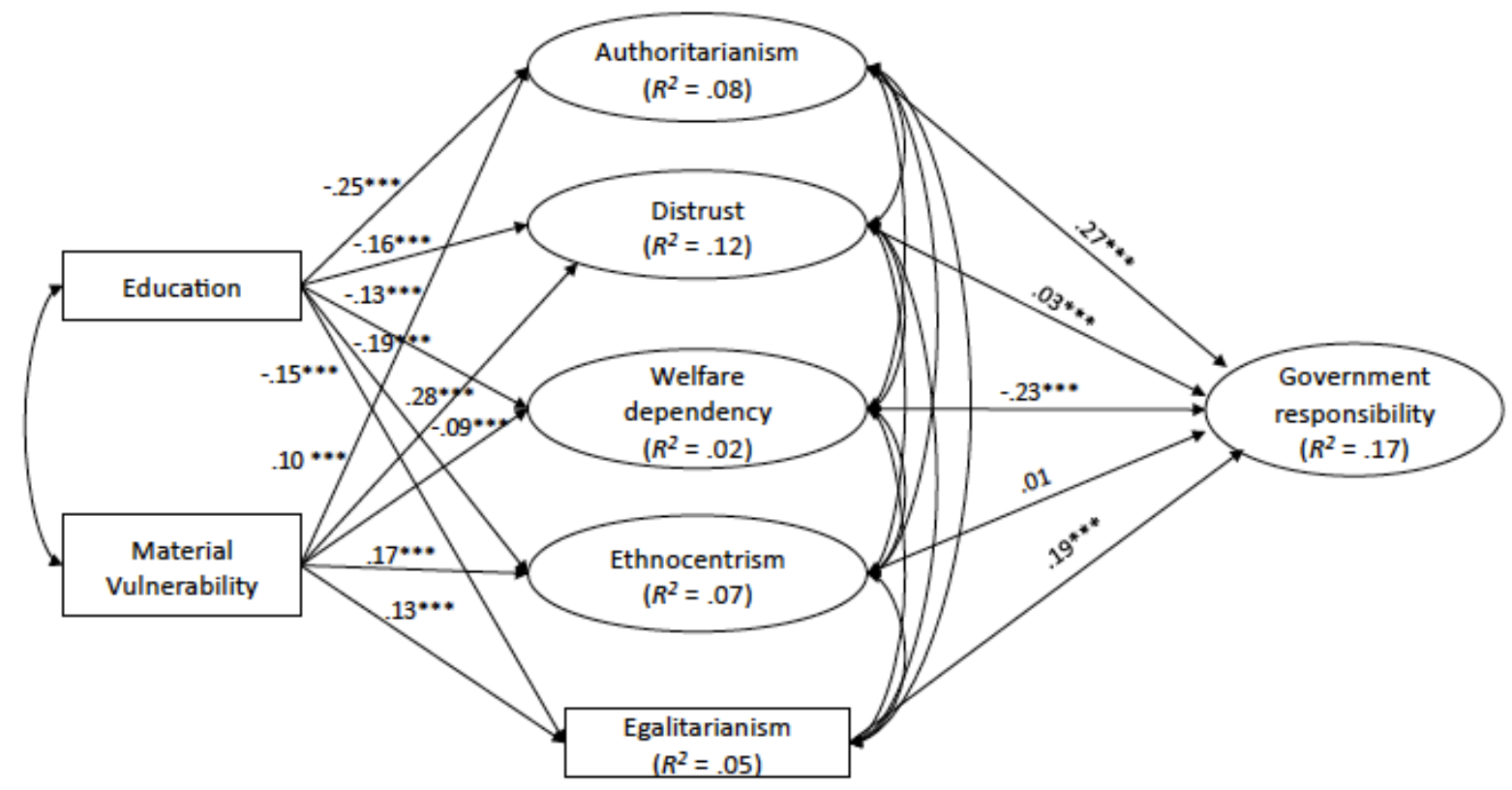

$* * *=p<.001$ 
Figure 5.3 Predicting government responsibility as a function of conceptions of social order across five welfare regimes

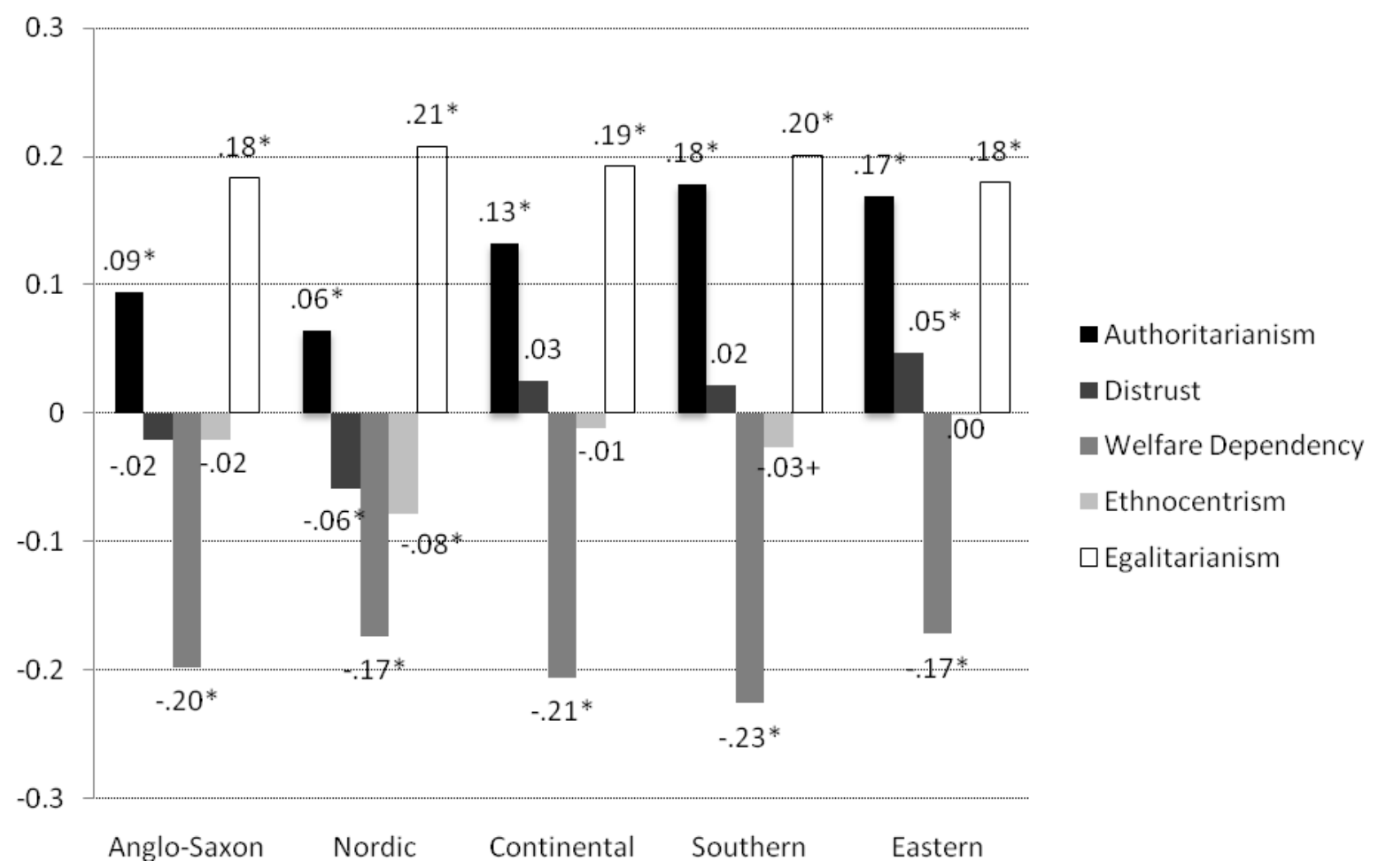

Note. Regression coefficients are standardized, and controlled for age, gender, and country within each regime cluster.

$*=p<.001,+=p<.05$. 
Figures 5.4a-c. Cross-level interactions on Government responsibility

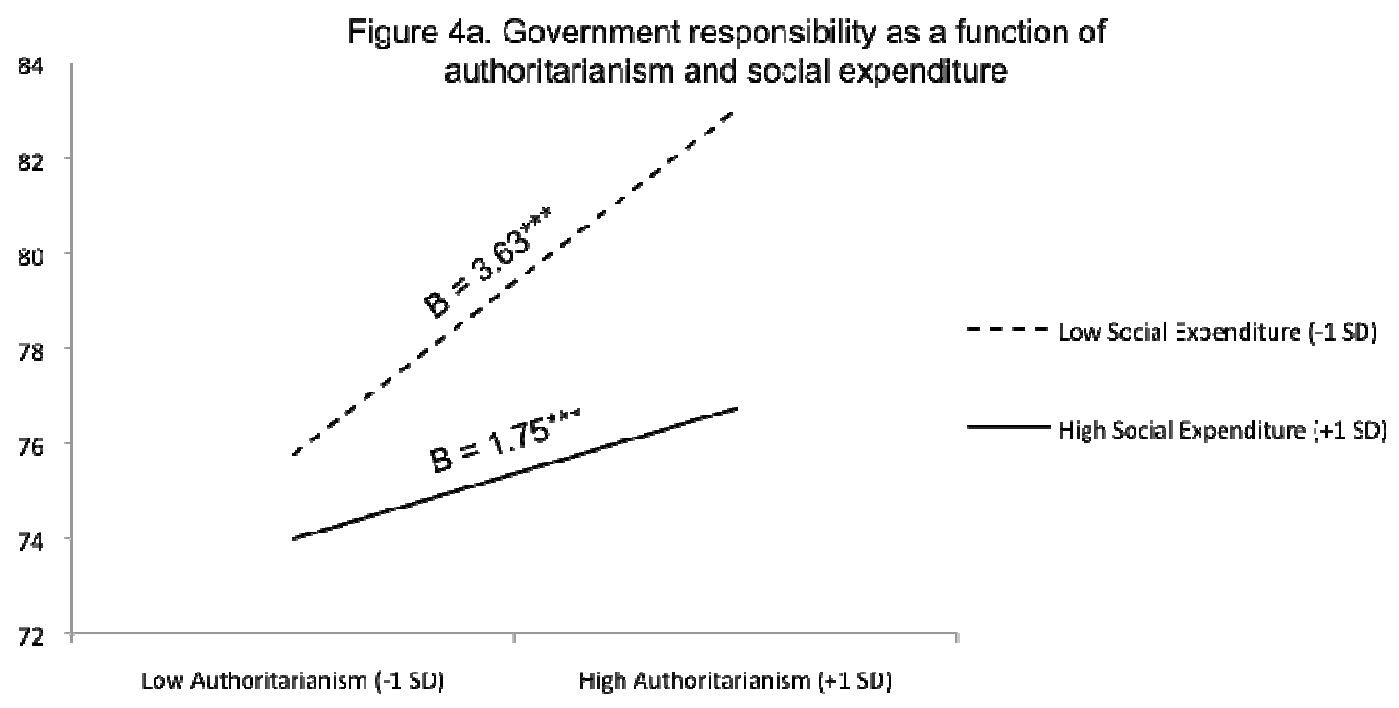

Figure $4 \mathrm{~b}$. Government responsibility as a function

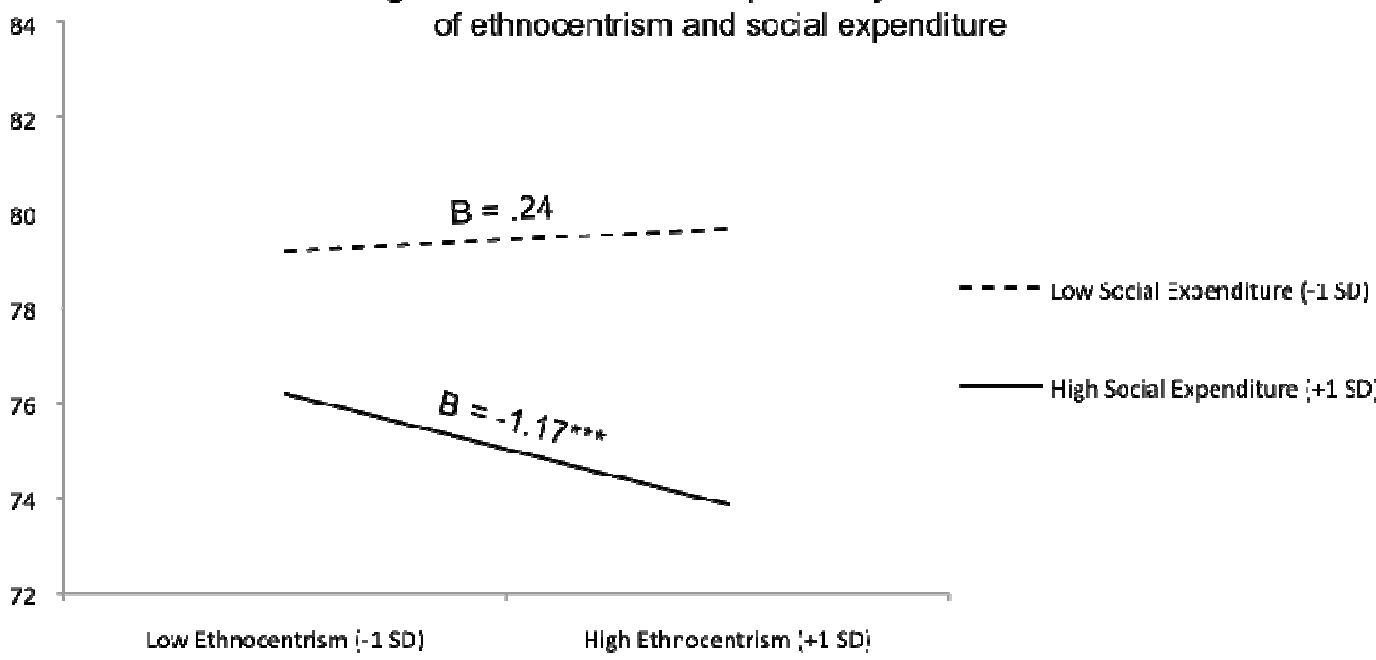

Figure 4c. Government responsibility as a function of

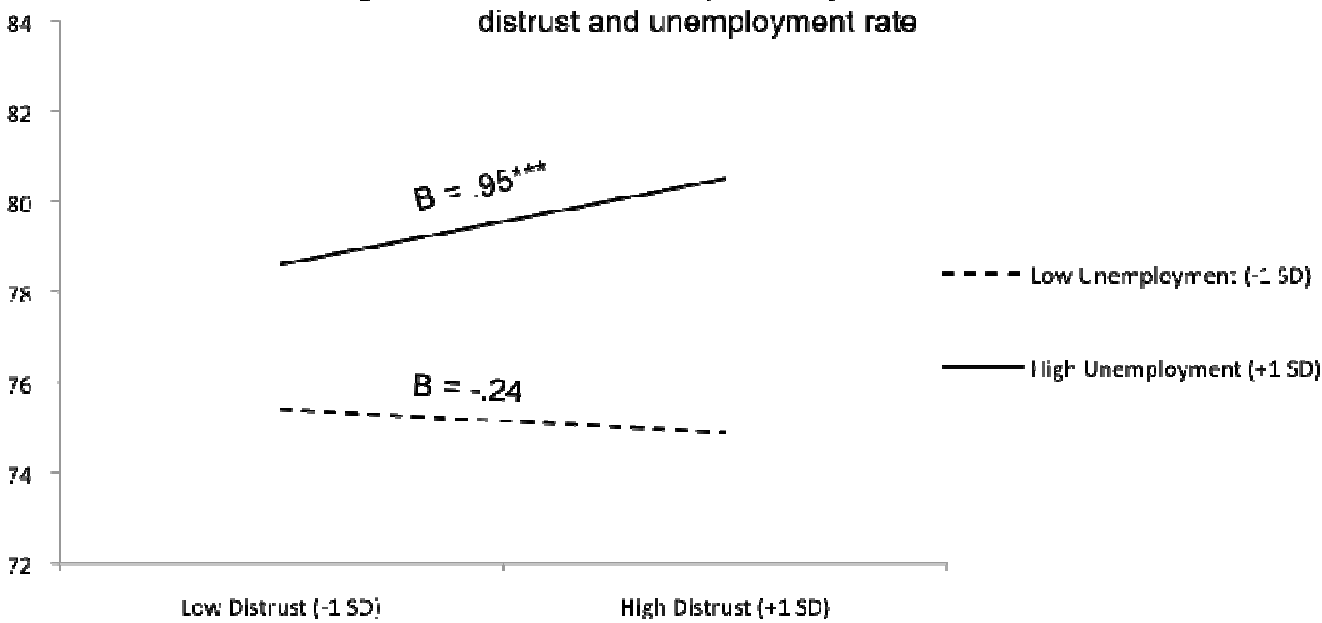

